\title{
Review of the genus Neoplatycerus Subba Rao, 1965 (Hymenoptera: Encyrtidae) of the word fauna with description of a new species from Australia
}

\author{
Oбзор рода Neoplatycerus Subba Rao, 1965 \\ (Hymenoptera: Encyrtidae) мировой фауны \\ с описанием нового вида из Австралии
}

\author{
Vladimir A. Trjapitzin \\ B.A. Тряпицын
}

Do vostrebovania, Post Office 129344 (ulitsa Letchika Babushkina, 7), Moscow, Russia.

До востребования, п/о 129344 (ул. Лётчика Бабушкина, 7), Москва, Россия

KEY WORDS: Hymenoptera, Encyrtidae, Neoplatycerus, Neoplatycerus tshernyshevi sp.n., Australia.

КЛЮЧЕВЫЕ СЛОВА : Hymenoptera, Encyrtidae, Neoplatycerus, Neoplatycerus tshernyshevi sp.n., Австралия.

ABSTRACT. Diagnosis of the genus Neoplatycerus Subba Rao, 1965, key to females of 4 known species and synopsis of them are provided. N. tshernyshevi sp.n. is described from Australia.

РЕЗЮМЕ. Статья содержит диагноз рода Neoplatycerus Subba Rao, 1965, определительную таблицу самок 4 его известных видов и их синопсис. Описан N. tshernyshevi sp.n. из Австралии.

\section{Introduction}

Neoplatycerus tshernyshevi sp.n. was found by me in the collections of the University of California (Riverside, USA) during my visit there in 1997. Previously described species of Neoplatycerus are primary endoparasitoids of mealybugs (Homoptera: Pseudococcidae) including those injurious to such important cultivated plants as grapes (Vitis vinifera), mango (Mangifera indica) and pomegranate (Punica granatum). They might be used in programs of classical biological control and integrated pest management. Earlier the genus Neoplatycerus was not indicated for Australia.

\section{Genus Neoplatycerus Subba Rao, 1965}

TYPE SPECIES : Neoplatycerus tachikawai Subba Rao, 1965, by original designation.

Subba Rao, 1965: 150-152; Hayat et al., 1975: 7, 18; Mani, 1981: 779-782; Noyes \& Hayat, 1984: 152, 306-307; Trjapitzin \& Trapitsyn, 2002: 203-210.

DIAGNOSIS. Female. Frontovertex very broad; ocelli form an obtuse triangle. Facial cavity either deep, delimited dorsally by a well-developed acute ridge, or shallow, delimited both dorsally and laterally, or only laterally, by acute margins. Antennae (Figs 1-3) inserted close to the mouth aperture, foliaceous, strongly broadened and flattened; scape with clearly (Fig. 1) or slightly (Fig. 3) curved ventral margin; dorsal outer flange of scape well developed; pedicel subtriangular; funicle $6=$ segmented, all its segments strongly transverse. Mandible with 2 teeth at apex. Maxillary palpus $4=$ segmented, labial palpus $3=$ segmented. Pronotum short. Mesoscutum without parapsidal lines. Wings not abbreviated; marginal vein of the forewing punctiform, stigmal vein strongly curved, postmarginal vein as long as or a little shorter than stigmal. Gaster with ovipositor sheaths not exerted; paratergites present in the type species. Body length 1.3$2.3 \mathrm{~mm}$.

Male (not known for N.tachikawai and N. tshernyshevi). Antennae (Fig. 2) not enlarged foliaceously, with scape slightly or moderatory broadened; all funicular segments somewhat wider than long, or $1^{\text {st }}$ segment subquadrate; clava entire, not truncate.

BIOLOGY. Endoparasitoids of mealybugs (Homoptera: Pseudococcidae), other data require confirmation.

DISTRIBUTION. Israel, Egypt, India, Malaysia, Australia. Materials from Malaysia were not identified to species [Noyes \& Hayat, 1984: 306-307].

SYSTEMATIC POSITION. Genus Neoplatycerus belongs to subfamily Tetracneminae, tribe Chrysoplatycerini, subtribe Chrysoplatycerina. It is closely related to the genus Ceraptrocerella Girault, 1918, known only from Australia. Neoplatycerus differs from Ceraptocerella in robust body (flatened in Ceraptocerella), absence of transverse band of dense white setae above the frontofacial ridge, absence of dark pattern on the forewing.

Key to WORLD SPECIES OF NEOPLATYCERUS (FEMALES)

1(2) Antennal scape not strongly narrowed basally (Fig. 3). $1.3-1.8 \mathrm{~mm}$ 4. N. tshernyshevi.

2(1) Antennal scape strongly narrowed basally (Fig. 1).

3(4) Antennal clava about as long as wide. Scutellum strongly convex. $2.3 \mathrm{~mm}$. 3. N. tachikawai.

4(3) Antennal clava distinctly longer than wide (Fig. 1). Scutellum not strongly convex. 
5(6) Facial cavity delimited dorsally by an acute ridge. Head and mesosoma black. Antennal scape dark, its outer side with strong green luster. Tibiae black. 1.09-1.45 mm ..

1. N. kemticus.

6(5) Facial cavity not delimited dorsally by an acute ridge. Head and mesosoma yellowish brown, apex of scutellum whith strong violet luster. Antennal scape yellowish with violet luster. Tibiae brownish. $2 \mathrm{~mm}$.

2. N. palestinensis

\section{Synopsis of species}

\section{Neoplatycerus kemticus V. Trjapitzin et S. Triapitsyn} (Figs 1-2).

Trjapitzin \& Triapitsyn, 2002: 205-208.

DISTRIBUTION. Egypt, ex Planococcus ficus Signoret and Planococcus sp. on grapes (Vitis vinifera).

\section{Neoplatycerus palestinensis (Rivnay, 1945)}

Rivnay, 1945: 119-121 (Tropidophryne - sic!); 1960: 224. (Tropidophryne, but probably the species belong to a new genus); 1968: 55 (Tropidophryne) Trjapitzin, 1971: 68 (not Tropidophryne); Kerrich, 1978: 150 (Tropidophryne, but a further assessment of the generic position of the species may be made); Trjapitzin, 1989: 125; Trjapitzin \& Triapitsyn, 2002: 204, 208-209.

DISTRIBUTION. Israel.

NOTE. The question concerning hosts of Neoplatycerus palestinensis is not simple, because data on them are rather contradictory. Rivnay [1945] indicated as a host of this species Eriopeltus sp. (Homoptera: Coccidae) on a «composite thistle» in Jerusalem. Without any doubt it was an error of rearing of the parasitoid; Encyrtidae of the subfamily Tetracneminae infest among coccoids only pseudococcids and eriococcids. In Rehovot, $N$. palestinensis was reared from the citrus mealybug Planococcus citri Risso on pomegranate
(Punica granatum), but now such identificftion of the host might be questionable, because there exists in Israel a similar species Planococcus ficus Signoret. In 2002, Prof. Yair BenDov (Rehovot, Israel) sent to me and to my son and co-author Dr. Serguei V. Triapitsyn a message and informed us that in 1987 he sent a material of N.palestinensis to Dr. John S. Noyes (London) who confirmed this identification. Ben-Dov determined then the mealybug host as Ferrisia virgata Cockerell, but in 2002 wrote that it was a misidentification, and the true name of this pseudococcid host is $F$. malvastra Mc Daniel (pers. comm.).

\section{Neoplatycerus tachikawai Subba Rao, 1965.}

Subba Rao, 1965: 150-152; Hayat et al.,1975: 18-20; Kerrich, 1978: 150-152; Mani, 1989; Hayat, 2006: 231.

DISTRIBUTION. India, ex Rastrococcus icerioides Green on mango (Mangifera indica). Indication of rearing of $N$. tachikawai from Iceria seychellarum Westwood (Homoptera: Margarodidae) is doubtful. A brief review of encyrtid genera connected with Margarodidae was published by Trjapitzin \& Triapitsyn [2006].

\section{Neoplatycerus tshernyshevi Trjapitzin sp.n.}

Fig. 3.

TYPE MATERIAL. Holotype female : Australia, SE Qld [ Southeast Queensland], Gatton, 11. IX. 1980 (Gordh \& Dahms); Neoplatycerus, det. V. A. Trjapitzin, 1997. The intact holotype specimen is card-mounted. Paratype female: the same labels as by the holotype; the specimen is card-mounted, with one antenna lost, another and left forewing detached and mounted on the slide ${ }^{1} 2$ Nal. in Canada balsam. Both holotype and paratype are preserved in the Entomology Research Museum, University of California, Riverside, USA.

DESCRIPTION. Female (holotype and paratype). Head, seen from above, wider than long (19:15). Occipital margin slightly concave, sharp. Inner orbits of eyes diverging anteriorly. Vertex about 3/8 head width; frontovertex, measured
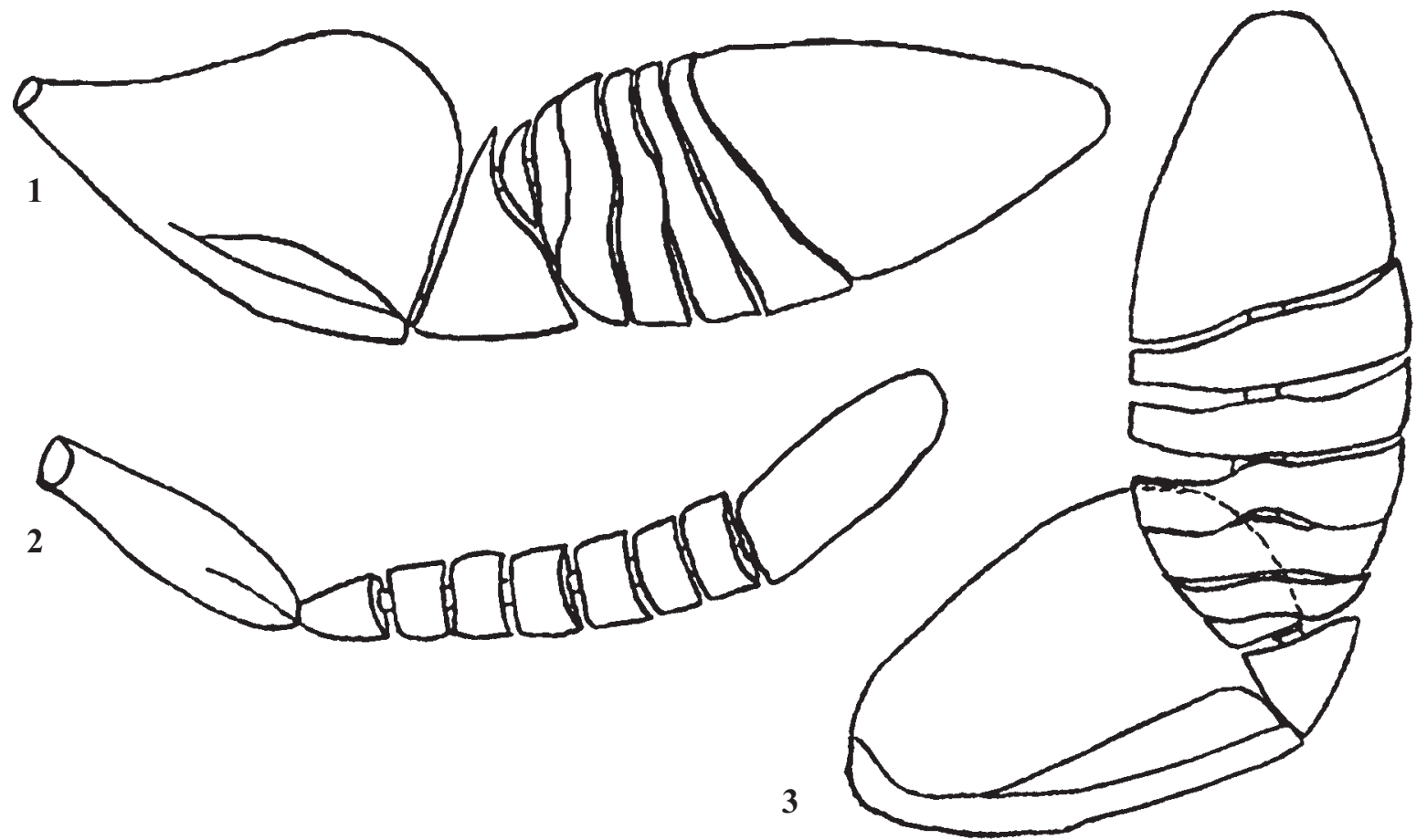

Figs 1-3. Neoplatycerus spp., antennae: 1-2 - N. kemticus; 3 - N. tshernyshevi sp.n., 1, 3 - female, 2 - male.

Ğèn. 1-3. Neoplatycerus spp., óñèèè: $1-2-N$. kemticus; $3-N$. tshernyshevi sp.n.; $1,3-$ nà̀êà, $2-$ ñài̊ö. 
along the middle, longer than wide $(5: 3)$. Apical angle of ocellar triangle somewhat more than $90^{\circ}$; distance between posterior ocelli more than distance from them to anterior ocellus (7:4) and to occipital margin (7:2); distance from posterior ocelli to eye margins less then diameter of an ocellus; distance from anterior ocellus to dorsal margin of facial cavity, formed by meeting scrobes, $3 \mathrm{x}$ more than to occipital margin. Facial cavity deep, not large, but broad, delimited dorsally and laterally by sharp keel; borders of the cavity almost vertical; dorsal margins of this cavity strongly concave (frontal view), frons depressed before it; interantennal prominence of face broad, convex , not reaching oral aperture. Toruli clearly above the level of lower eye margins; distance between toruli equal to distance from them to eye margins and $2 x$ more then distance to oral aperture. Malar space about $2 \mathrm{x}$ shorter than maximum height of eye; subocular suture present. Antenna as in Fig. 3. Pronotum very short, with slightly concave posterior margin. Mesoscutum $1.5 \mathrm{x}$ as wide as long. Scutellum somewhat convex, shorter than mesoscutum $(3: 4)$ and longer than wide $(4: 3)$, rounded at apex and with slightly curved lateral margins; apex of scutellum not overhanging propodeum. Mesopleura convex. Metapleura narrow, broadening dorsally. Wings not abbreviated; the forewing $2.7-3.0 \mathrm{x}$ as long as its maximum width; costal cell about $11 \mathrm{x}$ as long as wide, its anterior margin convex; anterior half of costal cell with hairs; linea calva interrupted in the middle with 7 very small hairs and closed with 1 row of hairs before posterior margin of the wing; apex of stigmal vein not rounded, with 3 sensilla in slightly curved line. Mesotibial spur $2 \mathrm{x}$ shorter than $1^{\text {st }}$ segment of mid tarsus. Propodeum in the middle about $1 / 3$ of scutellum length and 2x shorter laterally than scutellum. Gaster somewhat shorter than mesosoma, pygostyli situated near its base. Ovipositor sheaths scarcely exerted.

Head, pronotum, prothorax, mesopleura and metanotum more or less brown. Antennae, propodeum and gaster black. Mesoscutum, axillae and scutellum bronze-blue. Genae and malar spaces black with not strong greenish bronze luster. Tegulae and postspiracular sclerites dark, the latter with metallic luster. Forewings infuscate, but in their basal part (about 1/5 the wing length) more or less hyaline, except approximately $1 / 10$ the length of the wing at its base; apical 1/ 3 of the wing, measured along the middle, and its posterior $1 /$ 2 less infuscate. Fore legs brownish black or black, including tarsi. Mid and hind legs dark, with mid femora brown. Mesotibial spur yellow. Mid and hind tarsi white-yellow or yellow-white.

Frontovertex, interantennal prominence of face, mesoscutum, axillae and scutellum with minute cellular sculpture.

Body length $1.3-1.8 \mathrm{~mm}$.

Male unknown.

Host(s) unknown.

ETYMOLOGY. The new species is named after Prof. Wladimir Borisovich Tshernyshev (Chair of Entomology, Moscow State University, Russia).
DIAGNOSIS. Neoplatycerus tshernyshevi sp.n. is the only representative of the genus Neoplatycerus with antennal scape of female not narrowed strongly in basal part (Fig. 3). In all other described species of the genus scape is basally narrowed (Fig. 1).

ACKNOWLEDGMENTS. I am thankful to Dr. Alejandro González Hernández (Universidad Autónoma de Nuevo León, Monterrey, México) for preparation of computer images images of some body parts of the paratype of Neoplatycerus tshernyshevi sp.n. from which drawing was made by me.

\section{References}

Hayat M. 2006. Indian Encyrtidae (Hymenoptera: Chalcidoidea). Aligarh Muslim University (Aligarh, India). Published by M. Hayat. viii+496 p.

Hayat M., Alam S.M., Agarwal M.M. 1975 (1972). Taxonomic survey of encyrtid parasites (Hymenoptera: Encyrtidae) in India // Aligarh Muslim University Publications [Zoological Series] on Indian Insect Types. Vol.9. P.i-iii+1-112.

Kerrich G.J. 1978. A revision of the dinocarsiine Encyrtidae with a study of the genus Pelmatencyrtus De Santis (Hymenoptera : Chalcidoidea) // Zoological Journal of the Linnean Society. Vol.62. No.2. P.109-159.

Mani M.S. 1989. The fauna of India and adjacent countries. Chalcidoidea (Hymenoptera). Part. 1. Introduction. Agaonidae, Torymidae, Leucospididae, Chalcididae, Eurytomidae, Perilampidae, Eucharidae, Cleonymidae, Miscogasteridae, Pteromalidae, Eupelmidae and Encyrtidae. Madras, Nagaradj \& Co. xiv $+1067 \mathrm{p}$.

Noyes J.S., Hayat M. 1984. A review of the genera of Indo-Pacific Encyrtidae (Hymenoptera: Chalcidoidea) // Bulletin of the British Museum (Natural History). Entomology Series. Vol.48. No.3. P.131-395.

Rivnay E. 1945. Notes on Encyrtidae from Palestine, with the description of a new species // Journal of the Entomological Society of Southern Africa Vol.8. P.117-122.

Rivnay E. 1960. Notes on parasites of Planococcus citri Risso in Israel // Ktavim. Vol.10. Nos.3/4. P.223-224

Rivnay E. 1968. Biological control of pests in Israel. (A review 1905-1965) //Israel Journal of Entomology. Vol.3. No.1. P.1156.

Subba Rao B.R. 1965. A new genus of Encyrtidae from India (Hymenoptera) // Proceedings of the Royal Entomological Society of London (B). Vol.34. No.11-12. P.150-152.

Trjapitzin V.A. 1971. [Review of genera of Palaearctic Encyrtids (Hymenoptera, Encyrtidae) ] // Trudy Vsesoyuznogo Entomologicheskogo Obshchestva. T.54. P.68-155 [in Russian].

Trjapitzin V.A. 1989. [Parasitic Hymenoptera of the fam. Encyrtidae of Palaearctic]. Leningrad: Nauka Publishing. 488 p. [in Russian].

Trjapitzin V.A., Triapitsyn S.V. 2002. A new species of Neoplatycerus (Hymenoptera: Encyrtidae) from Egypt, parasitoid of the vine mealybug Planococcus ficus (Homoptera: Pseudococcidae) // Entomological News. Vol.113. No.3. P.203-210.

Trjapitzin V.A., Triapitsyn S.V. 2006. A new species of Brethesiella (Hymenoptera: Encyrtidae) from California, USA, a parasitoid of Steatococcus tabernicolus (Homoptera: Margarodidae) // Zootaxa. No.1167. P.1-16. 